\title{
Comparative International Law: The Scope and Management of Public Participation Rights Related to CCS Activities
}

\author{
Raíssa Moreira Lima Mendes Musarra \\ IEE/USP - Universidade de São Paulo \\ Brazil
}

Hirdan K. de Medeiros Costa

IEE/USP - Universidade de São Paulo, Brazil

Received: March 26, 2019 Accepted: May 7, 2019 Online published: May 21, 2019

doi:10.5296/jpag.v9i2.14559 URL: https://doi.org/10.5296/jpag.v9i2.14559

\begin{abstract}
The paper proposes the presentation of the public participation item in the regulatory standards of CCS in Australia, Canada, the European Union, the United Kingdom and the United States and their possible relations with the Brazilian configuration. The choice of territories is due to the existence of the item in its legal norms and or regulations. The standards available from the International Energy Agency (IEA) database on Carbon Capture, Transport and Storage were used. The methodology used is the comparative, cumulatively with the deductive method, assuming that public participation is a fundamental issue for the governance of CCS activities and that Brazil, when inserting such activities into its code, should take into account the adoption of the best practices of public participation, which, in addition to being consultative, provides deliberative powers to citizens.
\end{abstract}

Keywords: comparative international law, public participation, carbon capture, transport and storage

\section{Introduction}

Despite the lack of regulation of CCS (Carbon Capture, Transport and Storage) activities in Brazil, the use of such techniques for $\mathrm{CO} 2$ emissions mitigation or reduction is aligned with the National Policy for Climate Change objectives. Thus, it is important to understand whether and how specific jurisdictions deal with particular issues associated with $\mathrm{CO} 2$ 
storage. This paper proposes the presentation of the item of public participation in the regulatory standards of CCS existing in Australia, Canada, the European Union, the United Kingdom and the United States and their possible relations with the Brazilian configuration. The choice of territories is due to the existence of the item in its legal and/or regulatory rules. Thus, the work intends to expose and compare the treatment given to the item in the different territories, the tools related to it and its modes of execution.

The results may indicate appropriate ways to address public participation in CCS compatible with the tools of environmental governance in Brazil, or at least, to generate bases for the formulation of new forms of participation in the country.

It should be taken into consideration that this article has as a background public participation and its instruments for the effective consultation and deliberation of civil society, considering the decision terms of this participation.

Public Participation diverges from the field of "Public Perception". Public Perception is considered as a risk perception that emerged as a subdiscipline in 1969, stemming from the debates motivated by the article Social benefit versus technological risk, written by the engineer Chauncey Starr and published in the journal Science and that today has as a particular debate, about social and cultural factors that influence directly and indirectly the perceptions that individuals have about different risks (Di Giulio et al. 2015).

\section{Methodology}

The methodology used is the comparative one, which takes as reference the set of norms of the database of the IEA (International Energy Agency), with the presentation of the devices and the description of the configuration involved in the respective territories, in order to allow the observation of the treatment given to this important element of public action that is public participation. In addition, an exegesis is made for the adequacy of the Brazilian normative apparatus to the subject of public participation in relation to CCS activities in Brazil, which, with the use of the deductive method, assuming that public participation is a fundamental issue for the governance of CCS activities and that Brazil, when inserting such activities into its code, should take into account the adoption of the best practices of public participation, which, in addition to being consultative, provides deliberative powers to citizens.

\section{Discussion}

Carbon capture and storage activities, in the words of Monteiro Júnior, Xavier and Alves (2013), are about mitigation techniques to contain and reverse the accumulation of carbon dioxide in the atmosphere. From the observation of the problems caused by the excess of certain gases in the atmosphere, the anthropogenic sources of carbon emission need to be monitored for reversion of their impacts and the capture, consistent, among them, in the process of directing carbon dioxide to a given structure that contains it, avoiding its dispersion in the atmosphere, through the storage, which in general is the geological one.

Thus, according to Santos et al. (2017, pp. 238-9) disseminates the "use of technologies that 
imply the minimization of negative externalities to the environment". For the International Energy Agency (2018), carbon sequestration can be accomplished by natural means, through photosynthesis that is carbon removal from the atmosphere, or by artificial means, through Carbon Capture and Storage technologies. Because, once captured, the carbon dioxide is compressed and transported to suitable reservoirs. In short, the final storage of the carbon dioxide withdrawn from the atmosphere can be carried out in the hydrosphere, through ocean storage; in the biosphere, through storage by biomass; and in the lithosphere, through geological storage [(Santos et al., 2017) and (Almeida et al., 2017)].

However, if the activity is improperly developed, it can cause a compromise of the geological structure and cause fluid leaks to overlap or to the atmosphere (Costa et al., 2018).

These activities, therefore, can be understood as liable to cause damage to the environment, which, under the terms of item IV of article $225^{1}$ of the Federal Constitution of 1988, carries out a previous environmental impact study. And, in this area, for the purpose of adapting these activities to environmental regulation, it is pertinent to note that under the aegis of the instruments qualified in the Law of National Environmental Policy, namely, environmental impact assessment and licensing.

According to the International Energy Agency (IEA, 2016) legal and regulatory frameworks are key to ensuring that geological storage of $\mathrm{CO} 2$ is safe and effective and that the storage sites and risks that accompany it are managed properly. In this path, the regulation of public participation must emerge.

In this sense, researchers like Jacobi (1996) understands that there should be a strengthening of social and community organizations, redistribution resources through partnerships, information and capacity-building to participate the public spaces for decision-making and for the construction of institutions guided by a logic of sustainability.

This analysis takes into account the rules concerning the public participation of the International Energy Agency (IEA) included in the institution's CCS database.

\subsection{Standards EIA Norms about Public Participation}

\section{Greenhouse Gas Storage Act 2009 (Qld GHG Storage Act), Australia, Queensland}

The Queenslan GHG (Greenhouse Gases) Storage Law (sections 35, 114, 126) requires that GHG exploration, injection and storage requests include a statement by the applicant on how to consult and inform landowners and occupiers of public or private lands in activities are or will be carried out. In the case of issuing a license or lease for the exploration activities, injection and storage leases, the holder is obliged to consult each owner and occupant of the land in which the activities will be carried out.

The same law requires (section 339) to maintain an open registry for inspection by the public, allowing searches, extractions, and copies of documents (subject to fees). The registry,

\footnotetext{
${ }^{1}$ Art. 225 (...) Paragraph 1 In order to ensure the effectiveness of this right, it is incumbent upon the Public Power: (...) IV require, in the form of the law, for the installation of a work or activity potentially causing significant environmental degradation, a preliminary environmental impact study, which will be publicized.
} 
characterized as "GHG permit registration" should include operating licenses and storage leases, data acquisition and other arrangements.

The consultation should be about access and the carrying out of authorized activities for the GHG license (including, for example, the passage of access to land by permission), insofar as they relate to owners and occupants. It is also allowed the compensation for access and activities to the owners or occupants of the land by the holder of the activity.

It is seen, therefore, that public participation, in the case of this norm, is in fact of involvement with landowners and occupants, not contemplating the public in a broad sense.

Petroleum and Geothermal Energy Act 2000 (South Australia P\&GE Act), Australia, South Australia

The South Australia P\&GE Act addresses public participation so that everyone can access the public records of the Ministry corresponding to the environmental, namely:

Environmental Register: Contains copies of all environmental impact reports, environmental impact assessments, and approved environmental goal statements. Must be available for inspection without fee and copies of material in the record available for purchase. The public register: a register of licenses issued under the law, will also be available for inspection without fee, with copies of material in the registry available for purchase. The commercial register: records each document registering or conducting registrable negotiation in relation to a license, available for inspection only by persons authorized by the Minister or by someone with an interest in the license or negotiation.

Greenhouse Gas Geological Sequestration Act 2008 (Victorian Onshore Act), Australia, Victoria

Victorian Onshore Act seeks to establish a regulatory regime capable of ensuring effective public consultation and access to information regarding $\mathrm{CO} 2$ storage activities undertaken in Victoria. With a general obligation for authority holders to consult communities and municipal councils throughout the period of the authority, sharing relevant information and providing opportunities to respond.

A relevant implication is that applications for authorities not required to prepare an Environment Effects Statement under the Environment Effects Act 1978 must instead include a community consultation plan prepared in accordance with section 154, which in turn must be approved by the Minister prior to issuance of any permit.

If the authority is granted, copies of the approved community consultation plan must be provided to the community. Community consultation and conference requirements also apply for proposed injection testing plans and for proposed injection and monitoring plans. The Act also requires the Minister a publicly accessible greenhouse gas sequestration register which sets outs relevant information in relation to $\mathrm{CO} 2$ storage permits and activities.

The act is rich in details about the consultation and hearing procedures, including on how the consultation plan should be drawn up. 
Offshore Petroleum and Greenhouse Gas Storage Act 2010 (Victorian Offshore Act), Australia, Victoria

The Victorian Offshore Act requires the Minister to maintain records of formations declared as identified greenhouse gas storage formations, the record of which must be accessible over the Internet. Titles, including greenhouse gas assessment permits, leases, injection permits, special authorities and search authorities, whose registration must be available for inspection at convenient times, subject to the payment of a fee. In addition, the Law also allows the elaboration of regulations that allow the Minister to disclose monitoring information on stored substances of greenhouse gases. Thus, a standard is only mechanical to publish and access records rather than effective participation.

Oil and Gas Activities Act [SBC 2008] Chapter 36 (BC Oil and Gas Act), Canada, British Columbia

The British Columbia Oil and Gas Commission will maintain a record containing all the prescribed information on oil and gas activities (the term of which is set forth in section 1 to include the operation or use of a storage reservoir). The standard supposes the storage for this specific sector and only contemplates advertising through registration.

Petroleum and Natural Gas Act [RSBC 1996] Chapter 361 (BC Petroleum and Gas Act), Canada, British Columbia

According to this standard, all records and instruments related to leases of storage tanks registered under the Law must be open to public inspection free of charge subject to certain conditions.

For example, geological, geophysical and reports that are not well reported and well received by the ministry in the course of administering this law, and designated by the minister as confidential (being of public interest that is confidential), should not be released, except under an order of the Deputy Governor in the Council.

European Union Directive 2009/31/EC of the European Parliament and of the Council of 23 April 2009 on the geological storage of carbon dioxide and amending Council Directive 85/337/EEC, European Parliament and Council Directives 2000/60/EC, 2001/80/EC, 2004/35/EC, 2006/12/EC, 2008/1/EC and Regulation (EC) No 1013/2006 (EU CO2 Storage Directive), European Union

The Directive states that member states are required to make publicly available $\mathrm{CO} 2$ storage information in accordance with applicable laws.

"Member States shall make available to the public environmental information relating to the geological storage of CO2 in accordance with applicable Community legislation."

Thus, once again, a standard allows for public consultation and resolute participation of citizens, making clear the right to advertise information about storage.

United Kingdom Energy Act 2008 (UK Energy Act), European Union, United Kingdom, Northern Ireland, Scotland, Wales 
The Energy Act requires the Secretary of State to maintain registration with information relating to sequestration licenses granted under the Act; ensure that the register is available for inspection by the public free of charge; enable the public to obtain copies of entries in the register upon payment of a fee.

But the information may not be included in the register if the Secretary of State believes that disclosure of the information would be contrary to the interests of national security, or the licensing authority believes that disclosure of information would prejudice an individual's commercial interests, according to the rule.

Environmental Protection: Storage of Carbon Dioxide (Licensing etc.) Regulations 2010 No. 2221, European Union, United Kingdom, Wales, Northern Ireland, England

Regulation 9 of the UK CO2 Storage Licensing Regulations provides for the inclusion of the data of each license and storage license in the public registry to be established under section 29 of the Energy Act 2008. They shall include the terms and conditions of the license or permit; the names and addresses of all past and present holders of each license; The names and addresses of all past and present operators under each storage license; when a license has been terminated or delivered, the date of such termination or delivery; when a storage license has been revoked, the date and reasons for such revocation; and where a storage location has been closed, the closure date, maps and sections showing the spatial extent of the location and the storage complex, and the relevant post-closure plan. Participation allows only access to records.

\section{United States North Dakota Administrative Code Chapter 43-05 Geologic Storage of Carbon Dioxide (North Dakota Storage Administration Statute), United States, North Dakota}

The North Dakota Storage Management Statute provides that, on or before the date of the request for permission to operate a storage facility, applicants must first notify a number of different parties, including surface landowners, mineral rights and other porous space rights. within or near the relevant area. The consultation is restricted to such interests only. However, the North Dakota Commission should also issue a notification specifying the details of the permit application and the time and place where the Commission will hold a hearing on the request. Any objection to the request shall be submitted to the Commission in writing.

This rule, although it does not specify the procedure, provides for the possibility of admitting objections. It says:

The commission shall give at least $15 \mathrm{fteen}$ days' notice, except in an emergency, of the time and place of hearing thereon by one publication of such notice in a newspaper of general circulation in Bismarck, North Dakota, and in a newspaper of general circulation in the county where the land affected or some part thereof is situated, unless in some particular proceeding a longer period of time or a different method of publication is required by law, in which event such period of time and method of publication shall prevail. The notice shall issue in the name of the commission and shall conform to the other requirements provided by law. The public notice must state that an application has been led with the commission for 
permission to store carbon dioxide and describe the location of the proposed facility area and the date, time, and place of the hearing before the commission at which time the merits of the application will be considered.

\section{North Dakota Century Code Chapter 38-22 Carbon Dioxide Underground Storage (North Dakota CO2 Storage Statute), United States, North Dakota}

Following the same order as in the previous standard, the Storage Statute requires that a public hearing be held before a $\mathrm{CO} 2$ storage license is issued. The notice of the hearing must be published for two consecutive weeks in the official county newspaper or counties where the storage reservoir is to be located.

\section{Texas Administrative Code, Title 16: Economic Regulation, Part 1: Texas Railroad Commission, Chapter 5: Carbon Dioxide (Texas CO2 Code), United States, Texas}

Texas CO2 Code requires each applicant for a storage facility to file a copy of the application with the County Clerk at the courthouse of each county in which the proposed facility is to be located, in which case the application may be made available for the public to inspect and copy. Also, an electronic copy of the application must be provided to the Texas Railroad Commission, for publication on its website.

This is the first standard we analyze that provides for compulsory publication in digital media, allowing full access to copies.

Applicants to CCS Activities must: publish a general notice of any application for an original or amended storage facility; permit, three consecutive weeks in each newspaper of general circulation in each county where the storage facility is located or to be located; and notify a number of different parties who may be interested in or affected by the application, including holders of adjoining mineral interests, owners or lessees of overlying or adjoining surface lands and various administrative officials.

The standard provides "Permit approvals and hearings", thus:

If no protests against a permit application are received, the Director of the Commission's Oil and Gas Division may administratively approve the application. If, however, the protest is received from a person notified in accordance with the requirements outlined above, the Director must: notify the applicant that the application is not administratively approved; and schedule a hearing on the application. Where the Director administratively denies a permit application, the applicant may also request the Director to schedule a hearing. Following any hearing, the examiner must recommend the final action to be taken by the Commission.

Utah Code, Title 54: Public Utilities, Chapter 17: Energy Resource Procurement Act, Section 701: Rules for Carbon Capture and Geological Storage (Utah CCS Rules Statute), United States, Utah

The Utah CCS Rules Statute requires the Divisions of Water Quality and Air Quality to present to the Administrative Rules Review Committee recommended rules regarding $\mathrm{CO}$ capture and sequestration. These rules must provide adequate regulatory oversight and public 
information concerning carbon capture and sequestration.

Wyoming States, Title 35: Public Health and Safety, Chapter 11: Environmental Quality, Article 3: Water Quality (Wyoming Sequestration Permitting Statute), United States, Wyoming

The Wyoming Sequestration Permitting Statute requires the Administrator of the Water Quality Division of the Department of Environmental Quality to recommend to the Department Director rules, regulations and standards related to the permitting of $\mathrm{CO} 2$ sequestration. Although there is no specification of public consultation procedures, the standard provides that such recommendations may only be made after receipt of public comments.

Code of Federal Regulations, Title 40: Protection of Environment, Parts 144 (Underground Injection Control Program), 145 (State UIC Program Requirements) and 146 (Underground Injection Control Program: Criteria and Standards) (USA Underground Injection Rules), United States

The USA Underground Injection Rules take process for public participation in the consideration and approval of a State's application for primary enforcement responsibility: primacy in governing, within the that State's jurisdiction, underground injection control.

First, a public notice of its intent to adopt an underground injection control program and to seek primacy of this program initiates it.

The notice must "be circulated in a manner to attract the attention of interested persons; set out relevant information, including the fundamental aspects of the proposed program and when and where it can be reviewed by the public; provide for a comment period of at least thirty days; schedule a public hearing on the program no earlier than thirty days after publication of the notice; and identify a person who may be contacted for further information".

After, the Administrator is required to issue a public notice and will indicate that a public hearing will be held by the EPA, "which hearing must be held no earlier than thirty days after publication of the notice; provide for a public comment period of at least thirty days; and note the public availability of the application for inspection and copying. But, the EPA Regional Administrator may cancel the hearing if there is not sufficient public interest in it."

For each one of the hearing, it is necessary the following documents: (i) a responsiveness summary, (ii) identifying the public participation activities conducted, describing the matters presented to the public, summarizing significant comments received, and (iii) explaining the responses to these comments. It must be sent to who testified at the public hearing, and to others upon request.

Then, Code of Federal Regulations, Title 40 says:

Notice of this hearing must identify all of the Administrator's concerns, and be published in enough of the largest newspapers in the State to attract statewide attention. The hearing must 
be convened between sixty and seventy five days following publication of the notice, and all interested persons must be given the opportunity to make written or oral submissions at the hearing. Finally, it should also be noted that the process of developing the USA Underground Injection Rules involved significant public participation, including workshops, comment periods and hearings, and consultation with specific stakeholder groups such as industry associations, non-government organisations and Native American Tribes.

Louisiana Revised Statutes, Title 30: Minerals, Oil, and Gas and Environmental Quality, Chapter 11: Louisiana Geologic Sequestration of Carbon Dioxide Act (Louisiana CO2 Sequestration Act), United States, Louisiana

The Louisiana CO2 Sequestration Act enables any interested person to have the Commissioner of Conservation call a hearing with respect to any matter within the Commissioner's jurisdiction. The hearings must be conducted in accordance with other rule provisions, and be initiated by written request accompanied by the payment of an applicable hearing fee. The Commissioner must promptly call the hearing if the requirements are fulfilled. The Commissioner is required to keep a book of rules, regulations, and orders made under the Act, which book must be open for inspection: at all times during reasonable office hours; and on the website of the Department of Natural Resources. See Table 1 as an overview from each country analyzed.

Table 1. Brief of Public Participation

\begin{tabular}{|c|c|c|}
\hline Code & Jurisdiction & Public Participation \\
\hline $\begin{array}{l}\text { Greenhouse Gas } \\
\text { Storage Act } 2009\end{array}$ & Australia, Queensland & $\begin{array}{l}\text { Involvement with landowners and } \\
\text { occupants, not contemplating the public } \\
\text { in a broad sense. }\end{array}$ \\
\hline $\begin{array}{c}\text { Petroleum and } \\
\text { Geothermal Energy } \\
\text { Act } 2000\end{array}$ & Australia, South Australia & $\begin{array}{l}\text { Documents available for inspection only } \\
\text { by persons authorized by the Minister or } \\
\text { by someone with an interest in the license } \\
\text { or negotiation }\end{array}$ \\
\hline \multicolumn{3}{|l|}{ Greenhouse Gas } \\
\hline $\begin{array}{c}\text { Geological } \\
\text { Sequestration Act } \\
2008\end{array}$ & Australia, Victoria & $\begin{array}{l}\text { Details about the consultation and } \\
\text { hearing procedures }\end{array}$ \\
\hline $\begin{array}{l}\text { Offshore Petroleum } \\
\text { and Greenhouse Gas } \\
\text { Storage Act } 2010\end{array}$ & Australia, Victoria & $\begin{array}{l}\text { Standard is only mechanical to publish } \\
\text { and access records rather than effective } \\
\text { participation }\end{array}$ \\
\hline $\begin{array}{l}\text { Oil and Gas Activities } \\
\text { Act [SBC 2008] } \\
\text { Petroleum and }\end{array}$ & Canada, British Columbia & $\begin{array}{c}\text { Only contemplates advertising through } \\
\text { registration }\end{array}$ \\
\hline Natural Gas Act & Canada, British Columbia & Confidential \\
\hline
\end{tabular}

[RSBC 1996] 


\section{Macrothink Institute $^{i m}$}

European Union

Directive 2009/31/EC

and its amendments

United Kingdom

Energy Act 2008

Environmental

Protection: Storage of

Carbon Dioxide

(Licensing etc.)

Regulations 2010 No.

2221

North Dakota Storage

Administration

Statute

North Dakota CO2

Storage Statute

Texas CO2 Code

Utah CCS Rules

Statute

Wyoming

Sequestration

Permitting Statute

Code of Federal

Regulations, Title 40,

145,146

Louisiana $\mathrm{CO} 2$

Sequestration Act
Journal of Public Administration and Governance

ISSN 2161-7104

2019, Vol. 9, No. 2
European Union, United Kingdom,
Wales, Northern Ireland, England

European Union, United Kingdom,

Northern Ireland, Scotland, Wales
Standard allows for public consultation and resolute participation of citizens, making clear the right to advertise information about storage

Disclosure of the information would be contrary to the interests of national security

Allows only access to records.
United States, North Dakota

United States, North Dakota

United States, Texas

United States, Utah

United States, Wyoming

United States

United States, Louisiana
Consultation is restricted to interests only

Hearing must be published for two consecutive week

Permit approvals and hearings

Regulatory oversight and public information

No specification of public consultation procedures, it provides that such recommendations may only be made after receipt of public comments

Hearing, including workshops, comment periods and hearings, and consultation with specific stakeholder groups

Hearing and Commissioner is required to keep a book of rules opened

\section{Results}

Sustaining ecosystem recovery and economic growth are premises that must guide activities of production, circulation and distribution of goods and services, and the existence of norms gives the positive value to economic growth by sustaining the recovery of ecosystems. In addition, among actions that aim to meet the criteria of sustainable development of ecosystems recovery while maintaining economic growth and mitigating undesirable effects of anthropic origin in the environment, such as climate change and acidification of the oceans, are the activities of capture, storage and transport of carbon.

Acordding to OECD/IEA, Brazil's energy sector remains one of the least carbon-intensive in the world, although the absolute level of energy-related $\mathrm{CO} 2$ emissions grows by more than two-thirds to 2035, elevating the importance of this policy consideration. (OECD/IEA, 2013, p.397). 
According to Furriela (2002), participation is a concept that is only comprehensively understood if treated in conjunction with others, such as "democracy", "citizenship" and "citizens' rights". Pedro Jacobi (1996) argues that the concept of participation is permeated by contradictions and that the differences between city participation, social participation or community participation, or popular participation are not always clear. In general, it is understood that in the conceptual sphere, participation presupposes that state institutions take into account the interests and opinions of citizens before taking decisions or executing them (Borja, 1988, Jacobi, 1996, Furriela, 2002).

Jacobi (1996) clarifies that the consultative participation does not interfere directly in the decision-making process; already the resolute participation and the control participation imply the intervention in the course of the public activity.

To juridical participation, our constitution clearly opens up the possibility of collective procedural implementation (art. 129), and before that, the infra-constitutional ordainment already made possible the public civil action (Law 7.347/85) ${ }^{2}$.

In September 2016, Brazil completed the ratification process of the Paris Agreement, giving the United Nations official commitments to "reduce greenhouse gas emissions by $37 \%$ below 2005 levels in 2025 with a indicative reduction of greenhouse gas emissions by $43 \%$ below 2005 levels by 2030 "(MMA, 2018: 03).

In order to reach this goal, Brazil needs to think and adopt technologies such as Carbon Capture and Storage (CCS), according to Almeida et al. (2017), which may represent a strategic alternative for reducing $\mathrm{CO} 2$, especially for the energy sector. Despite this, the knowledge about this technology is still little consolidated between the country, as well as the regulation of these activities.

The Public Hearing is the moment of obtaining an environmental license of a work or activity in which the population can obtain details about its characteristics and impacts through the presentation of the Environmental Impact Report (RIMA). The documents of the public hearing (s) shall serve as a basis with the RIMA for e licensor to approve or not the project. (CONAMA, Res. 09/1987).

The Environment Agency should promote its realization when it is deemed necessary, or when requested by a civil entity, by the Public Prosecution Service, or by 50 or more citizens.

\footnotetext{
${ }^{2}$ Public Civil Action has the purpose of suppressing or even preventing damages to the environment, the consumer, the public patrimony, goods and rights of artistic, aesthetic, historical and tourist value, for infraction of the economic order and of the popular economy, to the public and social patrimony, to the honor and dignity of racial, ethnic and religious groups, and may have for object the condemnation in money or the fulfillment of obligation to do or not to do. The art. 5 of Law 7.347/85 brings the exhaustive role of legitimate entities to propose the public civil action: the Public Ministry; the Public Defender's Office; the Union, the States, the Federal District and the Municipalities; municipalities, public companies, foundations and joint-stock companies; the Federal Council of the Brazilian Bar Association (Law 8.906 / 94, article 54, subsection XIV); and associations which, at the same time, have been established for at least one year under civil law and include, among their institutional purposes, protection of the environment, consumer, economic order, free competition or artistic, aesthetic heritage, historical, tourist and landscape; the entities and organs of the public administration, whether directly or indirectly, even without legal personality, specifically for the filing of collective action (article 82, III, of the Consumer Protection Code, applicable in an integrated manner to the public civil action system, pursuant to article 21 of Law 7,347 / 85). Paragraph 1 of art. 129 of the CF states that The legitimacy of the Public Prosecution for the civil actions foreseen in this article (including environmental protection) does not prevent the third party, in the same hypothesis, according to the provisions of this Constitution and the law.
} 
The deadline for requesting the opening of a Public Hearing shall be 45 days after publication in the local press of the approval information by the environmental agency that the EIA / RIMA was approved. The call and opening of the public hearing does not have a pre-established deadline, but must have sufficient time for the interested parties to be able to organize themselves, take notice of the RIMA and attend the hearing.

Thus, even without specific legislation for ccs, we can perceive that there is openness to public participation at the moment of applying for environmental licensing in Brazil. However, we understand that other forms of participation, with power of deliberation, should be explicit.

\subsection{Lessons to be Learned}

The norms studied support information in the category of public participation. In this regard, there is no doubt that the right to the publicity of records, licenses and activities related to CCS activities is essential. However, access to copies is not free at all times and can sometimes be curtailed alongside "public safety", running in "secret" at the discretion of the state authority. In cases where public hearings and consultations are anticipated, the standards contain important efforts for dialogue, but it is not clear whether the demands raised have some priority of service, or even if there is a need to be answered, again leaving the decision for state authority.

Researches on popular participation in environmental issues in Brazil reveals that the general population has little information on the instruments of participation in these collegiate spaces and is not accustomed to participate, or even, does not have the technical qualification that is still demanded in these spaces to express their opinion (Castellano and Jacobi, 2010). Environmental education to promote an autonomy of social empowerment that vializes an emancipatory perspective (Camargo and Jacobi, 2010).

According to Bejamin (2011), in modern law, the legislator who attributes the benefit (environmental quality) or the mission (protecting the environment as everyone's duty also distributes means and procedural instruments and administrative means of participation, is the Brazilian case by article 225 of the CF of 1988. As the author observes, "without the possibility of collective, administrative and judicial questioning of the degrading behavior of third parties, any guarantee given to the citizen is engraved with the symbol of the infertility and inefficacy of the legal discourse".

An important observation from the analysis of the legislation pointed out is the lack of prediction of cooperation between States. Morato Leite (2011) affirms that are integral to the ideal of effective international cooperation elements such as duties to communicate, consultation, duty of assistance between countries, and prevent transfer of pollution. This cooperation, according to Morato Leite (2011), is not a monopoly of the states, which, at the internal level, must take public decision on measures to protect the environment, with close collaboration between legislators, polluters and affected citizens, as well as executives and spheres of public administration.

There is, in Brazil, an example of effective participation in demanding or challenging 
activities harmful to the environment, it is the Law. No. 7.802 / 89, which disciplines activities involving the use of agrochemicals, their components and the like. According to this law, certain organizations are entitled to request the cancellation or challenge of registration of agrochemicals and the like when they can harm the environment and the health of living beings.

They are: the class etudes, the political parties and the legally constituted entities for the defense of the diffuse interests related to the protection of the consumer and the environment. By adopting some mandatory procedures, the federal registration body must then pronounce, informing the applicant of the approval or rejection of the solution and publishing the decision in the Federal Official Gazette (Ferreira, 2011).

This example may serve for the CCS legislation to be implemented in the country to adopt a similar procedure or a more elaborate process of participation, conferring powers of intervention and deliberation.

\section{Conclusions}

Leite Lopes says that our society is immersed in what he calls the process of environmentalization, it means the characterization of the interiorization of the public environmental issue, these issues can be noted from of transformations in the form and language of social conflicts in their partial institutionalization, which characterizes the historical process, implying transformations in the State and in the behavior of the people (Leite Lopes, 2006). In this sense, when cultural laws involve taking a stand against reality implying recognition of the obligation of behavior, we have properly what is called a rule or norm (Reale, 2018: 29).

Clear is the urgency of Brazil to see the greater context that aims at understanding climate change mitigation strategies, their uses and impacts on society and the environment, which are fundamental elements for achieving environmental justice, which is a great propeller of international debates.

As discussed by Jacobi and Barbi (2007) the three mechanisms for civil society participation that are most relevant to environmental issues in Brazil are environmental councils, environmental impact reports and public hearings. The authors emphasize that there may be asymmetries of power and information in such processes.

Jacobi and Barbi (2007) portray the significant incentive of civil society participation in environmental protection activities with the creation of the National Environmental System (SISNAMA) and the Council Of the Environment (CONAMA) through advice and management committees of the Ministry of Environment. Even so, the involvement of social movements and community organizations has been uneven and has been in the majority of government representation.

Other instruments of popular participation are foreseen in the Brazilian Constitution: the popular initiative bill, the referendum and the plebiscite. There are also community councils in which representatives of the population can participate in decisions in various fields of 
government and public hearings in which the people must be informed and heard about projects, initiatives and decisions of the Legislative and Executive. (Dallari, 1999; Furriela, 2002).

As CCS activities in Brazil still lack regulatory standards, there is a need to include in legal debates and texts more democratic tools for participation, the existence of a collegiate body competent for the theme and with a significant chorus of civil society in them, aiming at the the CCS activities.

It is a good democratic conduct to include public participation before, during and after the regulatory process, both to discuss risk prevention and the ways in which ecosystems are managed and the social and political consequences of these directions in CCS processes.

\section{Aknowledgments}

The authors gratefully acknowledge support from FAPESP and SHELL Brasil through the 'Research Centre for Gas Innovation - RCGI' (FAPESP Proc. 2014/50279-4), hosted by the University of Sao Paulo, and the support given by ANP (Brazil's National Oil, Natural Gas and Biofuels Agency) through the R\&D levy regulation.

\section{References}

Benjamin, A. H. (2010). Constitucionalização do Ambiente e Ecologização da Constituição Brasileira. In: Canotilho, J. J. e Leite, J.R.M (Org.) Direito Constitucional Ambiental Brasileiro. São Paulo: Editora Saraiva, 2010, $4^{\text {a }}$ ed.

Brasil. Constituição. Brasil, 1988.

Castellano, M., \& Jacobi, P. R. (2010). Sinergia entre Poder Público e Sociedade na Gestão dos Recursos Hídricos nas Bacias dos Rios Piracicaba, Capivari e Jundiai- São Paulo. In: Ribeiro, Wagner Costa. (Org.). Rumo ao Pensamento Crítico Socioambiental. São Paulo: Annablume Editora, 01, 215-239.

Code of Federal Regulations, Title 40: Protection of Environment, Parts 144 (Underground Injection Control Program), 145 (State UIC Program Requirements) and 146 (Underground Injection Control Program: Criteria and Standards) (USA Underground Injection Rules), United States

Costa, H. K. D. M., \& Miranda, M. F., Musarra, R. M. L. M. M., \& Santos, E. M. (2018). Environmental License for Carbon Capture and Storage (CCS) Projects in Brazil, Journal of Public Administration and Governance, 8(3). https://doi.org/10.5296/jpag.v8i3.13430

Costa, H. K. D. M., \& Musarra, R. M. L. M. (2018). Salt Cave and Experimental Activity of CCS (Carbon Capture and Storage) in Brazil. (mimeo).

Dallari, D. A. (1999). Direitos Humanos e Cidadana.São Paulo: Moderna.

de Almeida, J. R. L., de Vasconcellos Rocha, H., de Medeiros Costa, H. K., \& dos Santos, E. M. (2017, April). The Analysis Of Civil Liability Regarding CCS. In New Energy Landscape: 
Impacts for Latin America, 6th ELAEE/IAEE Latin American Conference, April 2-5, 2017. International Association for Energy Economics.

Di Giulio, G. M., Vasconcellos, M. D. P., Günther, W. M. R., \& Ribeiro, H. A. J. V. (2015). Percepção de risco: um campo de interesse para a interface ambiente, saúde e $\begin{array}{llll}\text { sustentabilidade. Saúde } \quad e \quad \text { Sociedade, } & \text { 24(4), } & \text { 1217-1231. }\end{array}$ https://doi.org/10.1590/S0104-12902015136010

Environmental Protection: Storage of Carbon Dioxide (Licensing etc.) Regulations 2010 No. 2221, European Union, United Kingdom, Wales, Northern Ireland, England

European Union Directive 2009/31/EC of the European Parliament and of the Council of 23 April 2009 on the geological storage of carbon dioxide and amending Council Directive 85/337/EEC, European Parliament and Council Directives 2000/60/EC, 2001/80/EC, 2004/35/EC, 2006/12/EC, 2008/1/EC and Regulation (EC) No 1013/2006 (EU CO2 Storage Directive), European Union

Ferreira, H. S. (2011). Deveres ambientais na Constituição Federal de 1988. In: José Joaquim Gomes Canotilho; José Rubens Morato Laite. (Org.). Direito Constitucional Ambiental Brasileiro. 4ed.São Paulo: Saraiva, 2011, v. 1, p. 255-287.

Furriela, Rachel. Democracia, cidadania e proteção do meio ambiente. São Paulo: Annablume (2002).

Global CCS Institute, 2016. The Global Status Of CCS: 2016. Summary Report, Australia.

Greenhouse Gas Geological Sequestration Act 2008 (Victorian Onshore Act), Australia, Victoria

Greenhouse Gas Storage Act 2009 (Qld GHG Storage Act), Australia, Queensland

IBAMA. Instituto Brasileiro do Meio Ambiente e dos Recursos Naturais Renováveis. Available in <www.ibama.gov.br/>. Accessed in: March, 2018.

IEA (2016). Decoupling of global emissions and economic growth confirmed. 16 March 2016. International Energy Agency. [Online]: https://www.iea.org/newsroom/news/2016/march/decoupling-of-globalemissions-andeconomic-growth-confirmed.html

IEA GHG 2002. Transmission of CO2 and Energy. Transmission Study Report, 140.

IEA GHG 2014. CO2 Pipeline infrastructure. 2013/18, December, 2013.

IEA, 2007. Technology Roadmap: Carbon Capture and Storage. OECD/IEA, Paris.

Ingelson, Allan; Stevenson, Flora; Costa, Hirdan K. de M. The Environmental Impact Assessment Process for Offshore Oil and Gas E\&P in Brazil (mimeo), 2018.

IPCC, 1997: Revised 1996 IPCC Guidelines for National Greenhose Gas Inventories, J. T. Houghton et al. (eds), IPCC/OECD/IEA, Paris, France. Kennett, S.A., 2003. 
IPCC. (2003). Good Practice Guidance for Land Use, Land-Use Change and Forestry. Penman, J. et al. (eds),

IPCC/IGES, Japan. IPCC, (2000). Good Practice Guidance and Uncertainty Management in National Greenhouse Gas Inventories, J. Perman et al. (eds), IPCC/IEA/OECD/IGES, Japan.

Jacobi, P. R., \& Barbi, F. (2007). Democracia e participação na gestão dos recursos hídricos no Brasil. Rev. Katál. Florianópolis, $\quad$ 10(2), 237-244. https://doi.org/10.1590/S1414-49802007000200012

Jacobi, Pedro Roberto. Ampliação da cidadania e participação: desafios na democratização da relação poder público-sociedade civil no Brasil. Tese de Livre Docencia - USP. São Paulo. 1996.

[Online]

http://www.teses. usp.br/teses/disponiveis/livredocencia/48/tde-25102005-105004/pt-br.php.

Lawrence, S. et al. (2001). Persistence of Web References in Scientific Research. Computer, 34, 26-31. https://doi.org/10.1109/2.901164

Leite, J. R. M. (2011). Sociedade de Risco e Estado. In: Canotilho, Jose Joaquim Gomes e Leite, José Rubens Morato Leite. (Org.). Direito Constitucional Ambiental Brasileiro. 4ed.São Paulo: Editora Saraiva, 1, 151-226.

Leite, L., \& José, S. (2006). Sobre Processos de "ambientalização" dos conflitos e sobre dilemas da participação. Horizontes Antropológicos. Porto Alegre, 12(25), 31-64. https://doi.org/10.1590/S0104-71832006000100003

LEMES DE ALMEIDA, José Ricardo. ROCHA; Haline de Vasconcellos; COSTA, Hirdan Katarina de Medeiros; SANTOS, Edmilson Moutinho dos. The Analysis of Civil Liability Regarding CCS: Brazilian Case. No prelo. 2018.

Louisiana Revised Statutes, Title 30: Minerals, Oil, and Gas and Environmental Quality, Chapter 11: Louisiana Geologic Sequestration of Carbon Dioxide Act (Louisiana CO2 Sequestration Act), United States, Louisiana.

Ministério, d. M. A. (2017). Grupo Executivo sobre Mudança do Clima.[Online]: http://www.mma.gov.br/clima/grupo-executivo-sobre-mudanca-do-clima. Acesso em: 27 mar. 2018. 2018 b.

Ministério, d. M. A. (2018). Política Nacional sobre mudança do clima. [Online]: http://www.mma.gov.br/clima/convencao-das-nacoes-unidas/acordo-de-paris. Acesso em: 27 mar. 2018. 2018a.

Monteiro, J. J. V., Xavier, Y. M. D. A., \& Alves, F. G. (2013). A Regulação do Sequestro de Carbono no Brasil como instrumento de proteção do meio ambiente. Revista Direito e Energia, Ano 5, volume 8, ago/dez. Natal: UFRN.

North Dakota Century Code Chapter 38-22 Carbon Dioxide Underground Storage (North Dakota CO2 Storage Statute), United States, North Dakota.

OECD/IEA. World Energy $2013 . \quad$ [Online] 
https://www.iea.org/publications/freepublications/publication/WEO2013.pdf

Offshore Petroleum and Greenhouse Gas Storage Act 2010 (Victorian Offshore Act), Australia, Victoria.

Oil and Gas Activities Act [SBC 2008] Chapter 36 (BC Oil and Gas Act), Canada, British Columbia.

Petroleum and Geothermal Energy Act 2000 (South Australia P\&GE Act), Australia, South Australia.

Petroleum and Natural Gas Act [RSBC 1996] Chapter 361 (BC Petroleum and Gas Act), Canada, British Columbia.

Reale, M. (2018). Lições Preliminares de Direito. 40a Ed. São Paulo: Saraiva.

Santos, E. M., Costa, H. K. D. M., Romeiro, V., \& Parente, V. (2016). Energia de Combustíveis Fósseis e a Captura e Armazenamento de CO2. In: Lineu. (Org.). Sustentabilidade e energia. São Paulo: Manole, 209-247.

Texas Administrative Code. Economic Regulation, Part 1: Texas Railroad Commission, Chapter 5: Carbon Dioxide (Texas CO2 Code), United States, Texas

United Kingdom Energy Act 2008 (UK Energy Act), European Union, United Kingdom, Northern Ireland, Scotland, Wales.

United States North Dakota Administrative Code Chapter 43-05 Geologic Storage of Carbon Dioxide (North Dakota Storage Administration Statute), United States, North Dakota.

Utah, C. Public Utilities, Chapter 17: Energy Resource Procurement Act, Section 701: Rules for Carbon Capture and Geological Storage (Utah CCS Rules Statute), United States, Utah.

Wyoming, S. (2001). Public Health and Safety, Chapter 11: Environmental Quality, Article 3: Water Quality (Wyoming Sequestration Permitting Statute), United States, Wyoming

\section{Copyright Disclaimer}

Copyright for this article is retained by the author(s), with first publication rights granted to the journal.

This is an open-access article distributed under the terms and conditions of the Creative Commons Attribution license (http://creativecommons.org/licenses/by/4.0/). 